\title{
Permanent lake stratification caused by a small tributary - the unusual case of Lej da San Murezzan
}

\author{
Martin SCHMID* and Pema DORJI ${ }^{1)}$ \\ Swiss Federal Institute of Aquatic Science and Technology (Eawag), 6047 Kastanienbaum, Switzerland \\ ${ }^{1}$ UNESCO-IHE Institute for Water Education, Delft, the Netherlands, present address: Policy and Planning Division, Ministry of \\ Works and Human Settlement, Thimphu, Bhutan \\ *e-mail corresponding author: martin.schmid@eawag.ch
}

\begin{abstract}
Meromixis in temperate freshwater lakes is in most cases caused by (1) a morphometric predisposition combined with a high productivity that leads to anoxic conditions in the hypolimnion, (2) saline subsurface inflows, or (3) turbidity currents. Here we report an unusual case where meromixis is caused by the surface inflow of a small tributary. Lej da San Murezzan has been known for several decades to be salinity-stratified during winter, contrary to its neighbouring lakes Lej da Silvaplauna and Lej da Segl. To determine the cause of this stratification, vertical profiles of conductivity were measured on ten occasions between 27 September 2006 and 23 March 2007. An evaluation of these profiles showed that the salinity stratification was continuously built up by a salt source of approximately $5 \mathrm{td}^{-1}$. Ovel dal Mulin, a small tributary that contributes only about $1 \%$ to the total water inflows of the lake, was identified as the source of this salt. To our knowledge this is the first reported case of a lake where such a small unpolluted surface inflow leads to almost permanent salinity stratification. The salinity stratification has important consequences: it causes the lake to be meromictic with only occasional complete mixing instead of dimictic as the neighbouring lakes and thus supports the build-up of an anoxic bottom layer. Furthermore, it allows restratifying the cold water discharge from a recently installed heat pump within the hypolimnion without the risk of disturbing the ice formation at the lake surface by a rising plume.
\end{abstract}

Key words: meromixis, Lej da San Murezzan, salt balance, lake stratification

\section{INTRODUCTION}

\subsection{Meromixis in temperate lakes}

The vast majority of temperate and boreal lakes are either dimictic or monomictic. The combined forces of seasonal convection and wind are sufficient to completely mix them once or twice every year. In meromictic lakes, however, the stratification is stable enough to resist these forces, and the lake remains permanently stratified. In some cases, especially in warmer climates, complete mixing occurs sporadically every few years. Lakes with sporadic complete mixing were classified as oligomictic by Hutchinson (1957), but more recent classifications tend to include them with the meromictic lakes (Walker \& Likens 1975; Lewis Jr. 1983; Hakala 2003). Meromixis in lakes is caused typically by one of the following three processes: (1) a subsurface inflow of saline water stabilizing the hypolimnion of the lake (crenogenic meromixis); (2) a surface inflow of freshwater over a saline water body or a saline intrusion in a freshwater lake (ectogenic meromixis); (3) a combination of morphometric factors and high nutrient inputs (endogenic meromixis). In the latter case, high productivity and subsequent decomposition of organic matter lead to an anoxic hypolimnion, which facilitates the build-up of salinity stratification during summer. The energy required to overcome this stratification increases with lake depth, while the energy input from the wind increases with lake surface. Consequently, endogenic meromixis typically occurs in lakes with a high relative depth,

$$
z_{r}=z_{m} x \sqrt{\pi / 4 A}>0.05,
$$

where $z_{m}$ is the mean depth and $A$ is the surface area of the lake (Walker \& Likens 1975). Besides the major causes mentioned above, also road salt inputs have been shown to support meromixis in some lakes (Kjensmo 1997).

\subsection{Study site}

Lej da San Murezzan is one in a chain of lakes in the Engadin valley in the Eastern part of Switzerland (Fig. 1). It is situated at $1768 \mathrm{~m}$ a.s.l., has a surface area of 0.78 $\mathrm{km}^{2}$, a maximum depth of $44 \mathrm{~m}$, an average depth of 25 $\mathrm{m}$, and a total volume of $19.8 \times 10^{6} \mathrm{~m}^{3}$. The lake has one major inflow, the River Inn, which drains an upstream catchment area of $155 \mathrm{~km}^{2}$. The average discharge of the River Inn is $5.8 \mathrm{~m}^{3} \mathrm{~s}^{-1}$, peaking in summer with mean values around $15 \mathrm{~m}^{3} \mathrm{~s}^{-1}$ in June and July, and dipping during winter months from December to March $\left(1.4 \mathrm{~m}^{3} \mathrm{~s}^{-1}\right)$. The lake has several minor inflows which do not contribute significantly to the water balance. Most of these minor inflows are practically dry during winter time, except for the Ovel dal Mulin, which is fed by continuous groundwater sources and has a rather constant discharge of about 50 to $60 \mathrm{~L} \mathrm{~s}^{-1}$. The lake is usually frozen from mid 


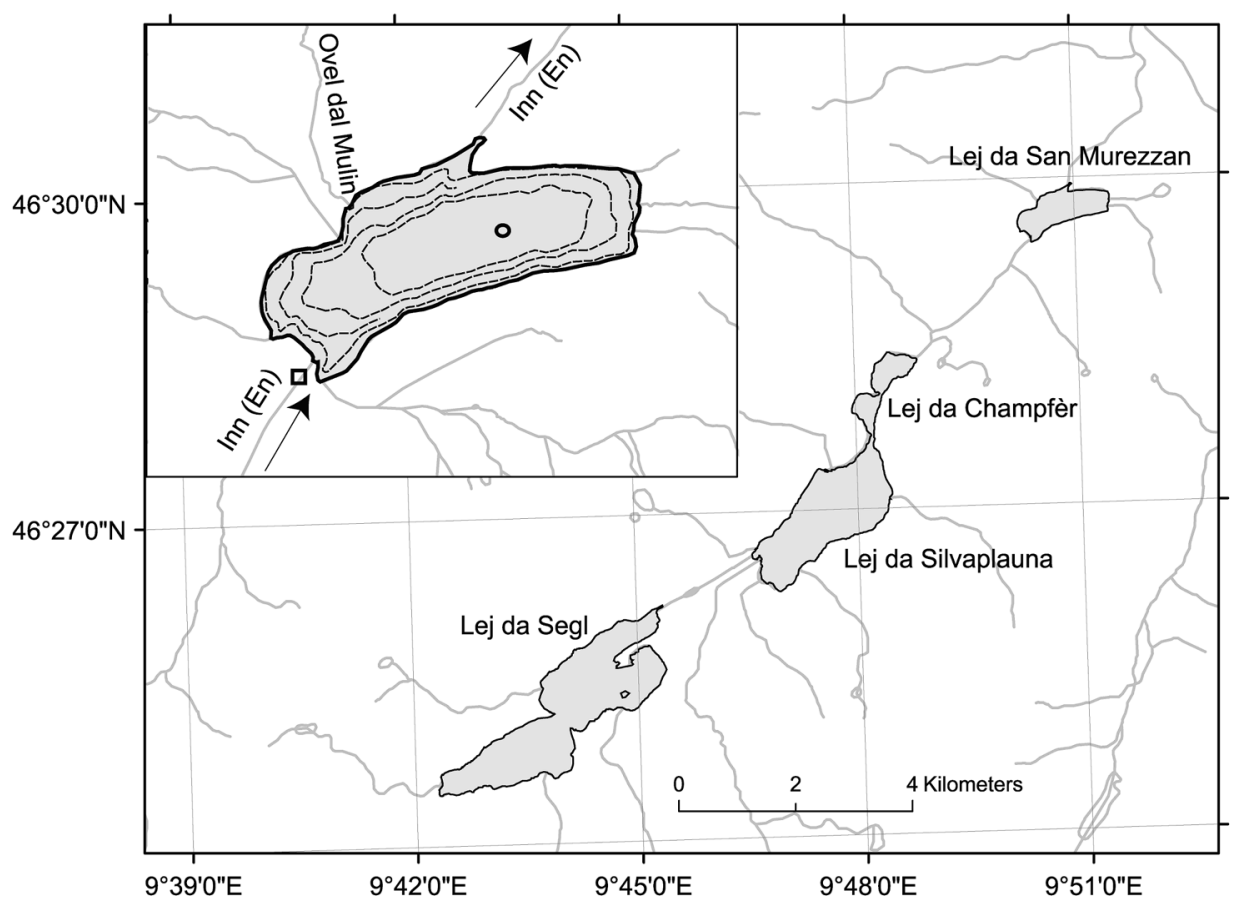

Fig. 1. Schematic map of Lej da San Murezzan and the upstream lakes. The inset shows a more detailed map of Lej da San Murezzan with $10 \mathrm{~m}$ equidistant elevation lines (lake surface $1768 \mathrm{~m}$ a.s.l., lines at 1760, 1750, 1740 and $1730 \mathrm{~m}$ a.s.1.), the two inflows discussed in this study, and the sampling locations in the lake (open circle) and in the River Inn (open square).

December until May. Various sport activities, including annual horse races, are regularly organized on the ice sheet. In December 2006, a heat pump was installed which withdraws $\sim 80 \mathrm{~L} \mathrm{~s}^{-1}$ water from $12 \mathrm{~m}$ depth and reinjects it at $35 \mathrm{~m}$ depth after cooling by $2-3{ }^{\circ} \mathrm{C}$. During the winter 2006/7 the heat pump was running only for a short period, but continuous winter operation is expected in the future.

\subsection{Results of previous studies}

The first study on the chemical stratification in Lej da San Murezzan was made by Schmassmann and Schmassmann (1948) in October 1946. They found that the lake was convectively mixed and saturated with oxygen down to $30 \mathrm{~m}$ on 9 October, while the epilimnion temperature was still above $10{ }^{\circ} \mathrm{C}$. Oxygen concentrations were below $2 \mathrm{mg} \mathrm{L}^{-1}$ beneath $32.5 \mathrm{~m}$ depth. One week later, oxygen concentrations in the deep water had already doubled due to continued convective mixing. Based on these observations, complete mixing most probably occurred in the following weeks. Eutrophication by the input of wastewater from St. Moritz was suggested as the cause for the low oxygen concentrations in the hypolimnion of this apparently dimictic lake. Nevertheless, the observed phosphate ( $\sim$ soluble reactive phosphorus) concentrations on the order of $10-20 \mu \mathrm{g} \mathrm{P} \mathrm{L}^{-1}$ were rather indicative of a mesotrophic lake.

Two decades later, Bosli-Pavoni (1971) measured vertical CTD (conductivity, temperature, depth) profiles in different seasons between October 1967 and October 1970. All profiles showed a salinity stratification in the hypolimnion, even though in October 1967 only the lowest few meters were stratified. Most intriguing was the only winter profile, which showed a strong salinity stratification with conductivity increasing from about $120 \mu \mathrm{S} \mathrm{cm}^{-1}$ at the surface to $170 \mu \mathrm{S} \mathrm{cm}^{-1}$ in the hypolimnion. This was in contrast to the two upstream lakes Lej da Segl and Lej da Silvaplauna, which showed no salinity stratification despite their larger depths of 71 and $78 \mathrm{~m}$, respectively. Average phosphate concentrations in March were $35 \mu \mathrm{g} \mathrm{P} \mathrm{L}^{-1}$, higher than previously observed by Schmassmann and Schmassmann (1948), but about one order of magnitude below the highest phosphate concentrations that were observed during the eutrophication peak between 1960 and 1980 in some lakes of the Swiss plateau (e.g., Wehrli et al. 1997). The higher nutrient input from domestic wastewater was again suggested to be the main difference to the upstream lakes and the major cause of the oxygen depletion in the deepwater.

The most detailed investigation on Lej da San Murezzan was made by Limnex (1994) on behalf of the canton Graubünden concerning the assessment of the effectiveness of the wastewater treatment plant that had been installed in St. Moritz in 1971. Besides their own measurements, they also collected and evaluated unpublished data from previous studies. Their main conclu- 
sions were as follows: the lake was assumed to be holomictic, i.e. completely mixing at least once every year, based on the fact that several autumn profiles indicated mixing down to $35 \mathrm{~m}$ depth while the water temperature was still above $4{ }^{\circ} \mathrm{C}$. Nevertheless, in 1992 an oxygen deficit had been observed in the hypolimnion in June, suggesting that mixing had not reached the deepest layers in the spring. Thanks to wastewater treatment, total $\mathrm{P}$ concentrations had approached the lower values of the two upstream lakes on the order of $10 \mu \mathrm{g} \mathrm{L}^{-1}$. But the volumetric oxygen consumption in the hypolimnion was still about 3 times higher in Lej da San Murezzan than in Lej da Silvaplauna or Lej da Segl. This was mainly due to the lower ratio between the hypolimnion and the epilimnion in Lej da San Murezzan, while the oxygen consumption per unit area was similar in all three lakes.

Both Schmassmann and Schmassmann (1948) and Limnex (1994) indicated that the lowest part of the hypolimnion was stratified mainly due to elevated concentrations of gypsum $\left(\mathrm{CaSO}_{4}\right)$ and suspected that the river Ovel dal Mulin (see below) and/or groundwater inputs could contribute to this stratification. Altogether, three conductivity profiles were measured under the ice cover during winter (Fig. 2). All of them indicated a very similar winter stratification pattern, with a surface conductivity (corrected to $25{ }^{\circ} \mathrm{C}$ ) of $120-140 \mu \mathrm{S} \mathrm{cm}^{-1}$, a strong gradient in the top $10 \mathrm{~m}$, and a weaker steady gradient in the hypolimnion. Such winter salinity stratification is rather unusual in a lake that is assumed to be dimictic, but nevertheless its cause has never been investigated in detail.

Before the installation of the heat pump in December 2006, there were some concerns that the reinjected water might form a plume that could reach the surface and thus disturb ice formation on the lake. Simulations of the discharge plume showed that this scenario could not be excluded if the lake was not stratified or only slightly stratified by temperature (M. Schmid and D. McGinnis, unpublished data). However, since the lake is salinity stratified during winter, the discharge plume, which is designed to mix quickly with ambient water, restratifies within a few meters distance from the injection depth and does not disturb the ice formation.

\subsection{Aims of the present study}

The results of the previous studies showed that the salinity stratification of Lej da San Murezzan has two major consequences: it supports the build-up of an anoxic hypolimnion both during winter and during summer, and it allows restratifying the heat pump discharge plume without any risk of disturbing the ice formation. The aim of the present study was therefore to verify the cause of this winter salinity stratification and to determine whether it leads to permanent or temporary meromixis. This is a prerequisite for future management of the lake both concerning the effects of the heat pump

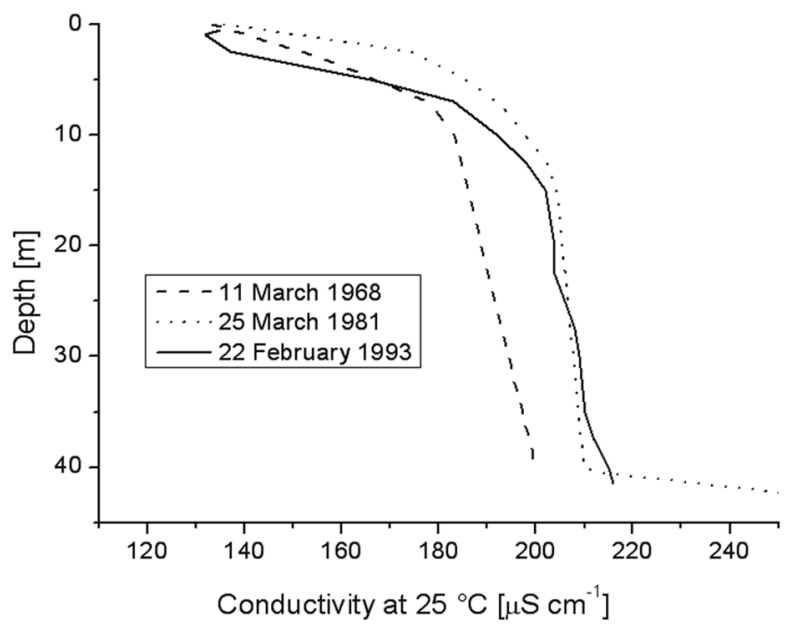

Fig. 2: Conductivity profiles observed under the ice in Lej da San Murezzan in March 1968 (Bosli-Pavoni 1971), March 1981 (data from H. Züllig, in Limnex [1994]), and February 1993 (Limnex 1994).

discharge, and the evaluation of possible measures to avoid oxygen depletion in the hypolimnion of the lake.

\section{MEASUREMENTS AND METHODS}

One or several vertical CTD profiles were measured with a Richard Brancker RBR XR-420 CTD probe on the following dates: 26 January, 27 September, 17 and 26 October, 6 and 22 November, and 12 December 2006; 11 January, 7 February, 1 and 23 March, and 17 July 2007. On 6 and 22 November, and 12 December 2006, and on 11 January and 17 July 2007 dissolved oxygen profiles were measured using one or two RBR TDO-2050 probes attached to and started simultaneously with the XR-420. The RBR XR-420 was also used occasionally to measure the conductivity and temperature of the major inflows.

The temperature and conductivity of the River Inn were continuously measured from 17 October 2006 to 1 March 2007 using a Richard Brancker RBR XR-420 CT probe at the location indicated by an open square in figure 1 . To check the representativeness of the sampling location that could potentially have been influenced by the upstream discharge of the cooling system of the nearby ice rink on the same shore, an additional Vemco temperature logger was installed on the opposite shore.

Water samples were taken on 26 October 2006 from $0,10,20,30$ and $38 \mathrm{~m}$ depth, on 11 January 2007 from $2.5,10,20,25,30,35$ and $40 \mathrm{~m}$ depth, on 17 October 2006 from all major inflows, and on 11 January 2007 from Ovel dal Mulin and the River Inn. An additional water sample from Ovel dal Mulin was taken on 23 March 2007. The main ionic composition of all water samples was determined using a Metrohm Advanced Compact IC with a Metrosep C2/100 4.0 column for the 
cations and a Metrohm Detector 732 with 753 suppression module and a Metrosep A Supp 5 150/4.0 column for the anions. On 11 January 2007 oxygen concentrations in the lake water samples were measured using the Winkler method.

All the salinities given below were calculated using the approach of Wüest et al. (1996) from observed insitu conductivities and temperatures, the surface water ionic composition measured in Lej da San Murezzan in the sample from 26 October 2006, and the equivalent conductivities of the individual ions. The same ionic composition was used for all calculations. For the range of compositions observed in the lake and the Ovel dal Mulin, this could produce errors in the salinity estimates of no more than $5 \%$. The average difference between salinities calculated from conductivity and the sum of the observed ion concentrations in the lake water samples was $3.6 \%$ (see also Figs 3 and 6), with a bias of $2.7 \%$ that might be due to ions not included in the analysis, like iron, manganese or nitrate. However, sulfate at low concentrations has a higher specific conductivity than the average lake water. The diluted salt input from Ovel dal Mulin would therefore increase conductivity by up to $25 \%$ more than calculated using the lake ionic composition. The effects of this potential error source are discussed in more detail below. We abstained from using different compositions for different datasets, as this would also lead to artefacts in the salt mass balance.

\section{RESULTS AND DISCUSSION}

\subsection{The cooling phase in autumn 2006}

The observed development of the stratification in Lej da San Murezzan can be split up in two phases. The cooling phase from 27 September to 12 December 2006 is shown in figure 3. During these 76 days the epi- limnion temperature decreased from 12.7 to $4.3{ }^{\circ} \mathrm{C}$. As the vertical salinity profiles depict, the convective mixing extended to a depth of $25 \mathrm{~m}$ on 22 November 2006, and probably to a maximum of about $28 \mathrm{~m}$ depth a few days later. The water column below $32 \mathrm{~m}$ depth was completely unaffected by convective mixing in autumn 2006.

On 12 December 2006, a thin ice sheet of about $3 \mathrm{~cm}$ thickness had already formed on large parts of the lake surface, four days before the average date of complete ice-cover formation during the years 1977 to 1993 (D. Livingstone, pers. comm.). This was rather surprising, since the autumn 2006 had been the warmest ever recorded in Switzerland. Temperatures at the nearest station of MeteoSwiss in Samedan had been almost continuously several degrees above average from 1 September until 8 December (Fig. 4). However, 3 days in a row with an average temperature of $-9.5^{\circ} \mathrm{C}$ and wind speeds below $1 \mathrm{~m} \mathrm{~s}^{-1}$ were sufficient to build up an inverse stratification at the surface and allow the formation of a thin ice cover. This coincidence of low air temperatures and weak winds with the time when the epilimnion temperature approached the temperature of maximum density of $4{ }^{\circ} \mathrm{C}$ was most probably the reason why convective mixing did not extend below $28 \mathrm{~m}$ depth.

The epilimnion salinity increased from $0.106 \mathrm{~g} \mathrm{~L}^{-1}$ to $0.130 \mathrm{~g} \mathrm{~L}^{-1}$ during the cooling phase, mainly due to mixing with the more saline hypolimnetic water. Between 22 November and 12 December 2006, an intrusion of more saline water occurred at depths between 21 and 26 $\mathrm{m}$. The salinity of this water layer increased to about $0.150 \mathrm{~g} \mathrm{l}^{-1}$, in agreement with a salinity peak observed in the conductivity of the River Inn between 7 and 12 December. The average discharge of the River Inn during these days was $2.5 \mathrm{~m}^{-3} \mathrm{~s}^{-1}$ (FOEN 2007), i.e. a total of about $1.1 \times 10^{6} \mathrm{~m}^{3}$ with a salinity above $0.15 \mathrm{~g} \mathrm{~L}^{-1}$
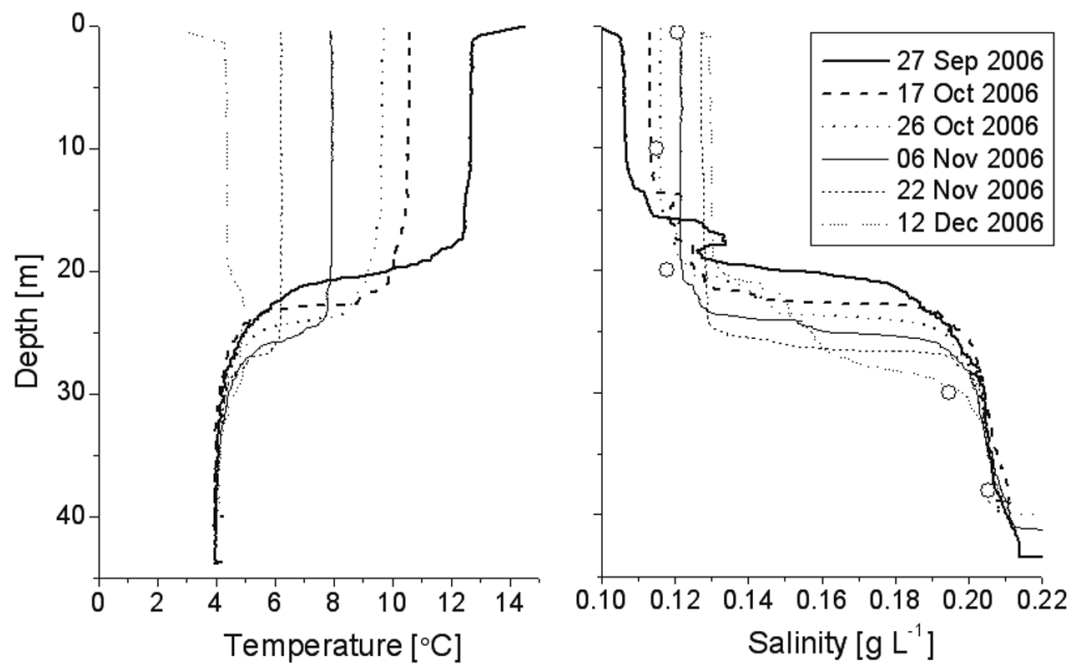

Fig. 3. Vertical temperature and salinity profiles observed in Lej da San Murezzan during the cooling phase in autumn 2006. The circles indicate salinities calculated from the ion concentrations measured on 26 Oct. 2006 (Tab. 1). 

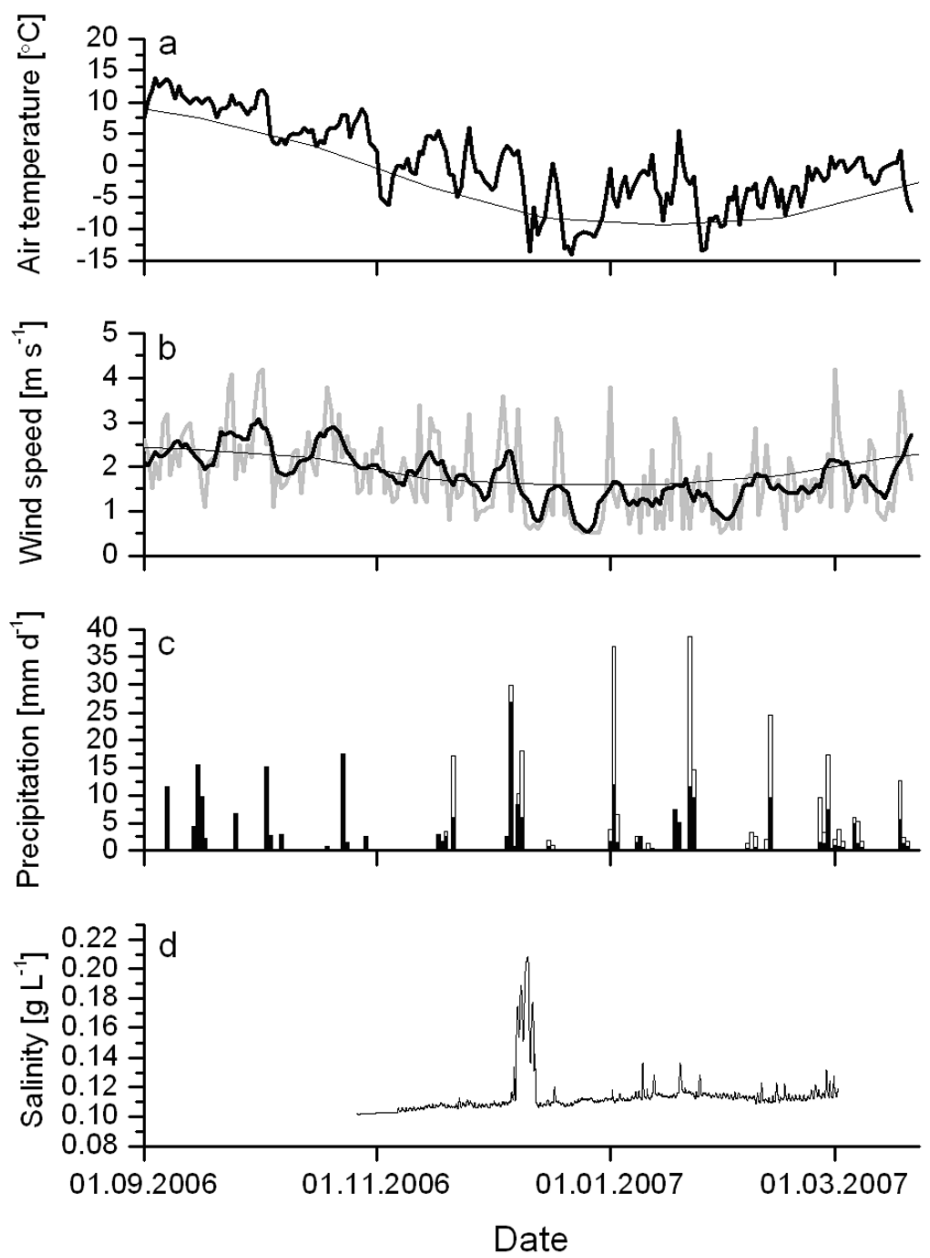

Fig. 4. Observed a) air temperature (bold line) compared to monthly average from 1961 to 1991 (thin line), b) wind speed (grey line: daily averages, bold black line: weekly running averages) compared to monthly mean from 1961 to 1991 (thin line), c) precipitation (black bars: rain, white bars: snow), and d) salinity calculated from observed conductivity in the River Inn, between 1 September 2006 and 23 March 2007. The meteorological data is from the meteo station of MeteoSwiss in Samedan.

entered the lake just before the profile on 12 December was measured. This intrusion further eroded the chemocline, weakening the salinity gradient, and the Inn water partially mixed with the water between 21 and $30 \mathrm{~m}$ depth which had a higher average temperature and a similar average salinity (higher above and lower below the chemocline). The lake volume in this depth range is about $4 \times 10^{6} \mathrm{~m}^{3}$. As both rain and snow in combination with cold temperatures preceded the salinity peak and since snow from the streets of St. Moritz is partially dumped into the River Inn upstream of our measurement site, we suspected road salt to be the source of this salinity peak. However, this should have led to significantly higher chloride concentrations than those observed in the lake. The origin of this salinity peak therefore remains unclear. The salt balance for the cooling phase is shown in figure 5 . The continuous chemocline erosion caused a net transport of salt from below the chemocline to the epilimnion. In the last time step between 22
November and 12 December 2006, the salt input from the River Inn discussed above appears at 21 to $26 \mathrm{~m}$ depth.

\subsection{The formation of salinity stratification in winter 2007}

After the formation of the ice sheet and the build-up of the inverse temperature stratification, the situation in Lej da San Murezzan changed completely. The River Inn had a weak discharge that was most of the time below $2 \mathrm{~m}^{3} \mathrm{~s}^{-1}$, and because of its low temperature and conductivity, it permanently flowed through the surface layer of the lake. Below $6 \mathrm{~m}$ depth, salinity continuously increased (Fig. 6), building up a stratification similar to observations in previous winters (Fig. 2). Except for the top few meters, temperature had no significant influence on stratification.

The salt balance (Fig. 7) showed a large input 


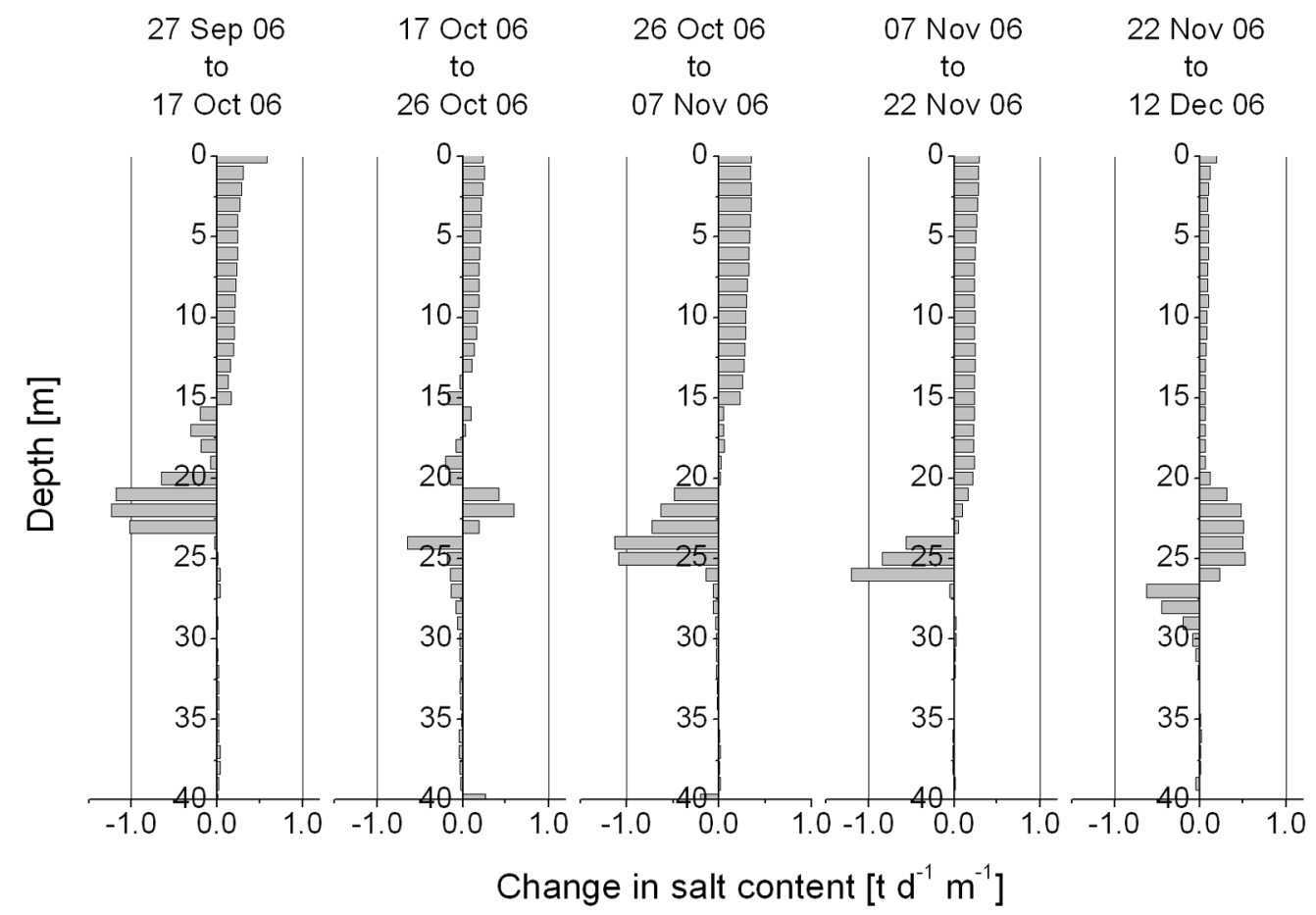

Fig. 5. Average daily salt balance during the cooling phase in autumn 2006 in Lej da San Murezzan, calculated from the CTD profiles shown in figure 3 .
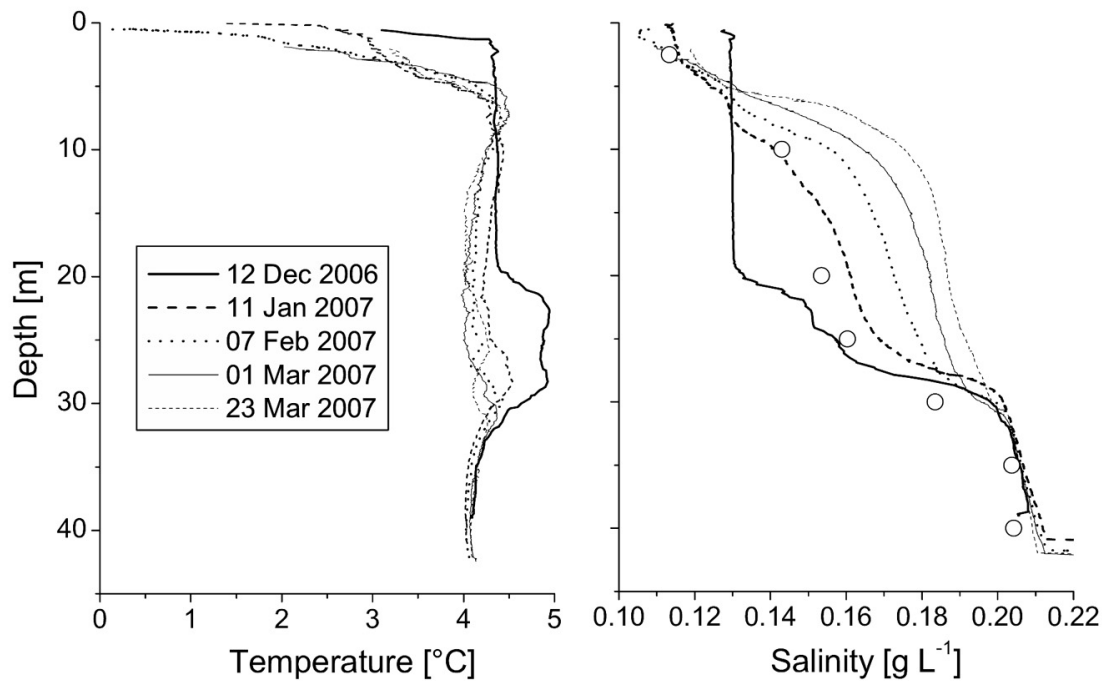

Fig. 6. Vertical temperature and salinity profiles observed in Lej da San Murezzan during the winter stratification between December 2006 and March 2007. The circles indicate salinities calculated from the ion concentrations measured on 11 January 2007 (Tab. 1).

between 6 and $30 \mathrm{~m}$ depth. The total input between 17 December 2006 and 23 March 2007 was 520 t salt. The comparison of the ionic compositions from 26 October 2006 and 11 January 2007 showed that the increase was mainly due to inputs of calcium and sulfate, while the concentrations of carbonate remained almost constant, and those of chloride were permanently low (Tab. 1).
This indicates that neither biological processes nor the input of road salt were responsible for the build-up of the salinity stratification. Since the equivalent conductivity of calcium sulfate at low concentrations is higher than that of the average ionic composition of the lake, the true salt input was probably up to $25 \%$ lower $(\sim 400 \mathrm{t})$.

The most probable source of the salt is the small 


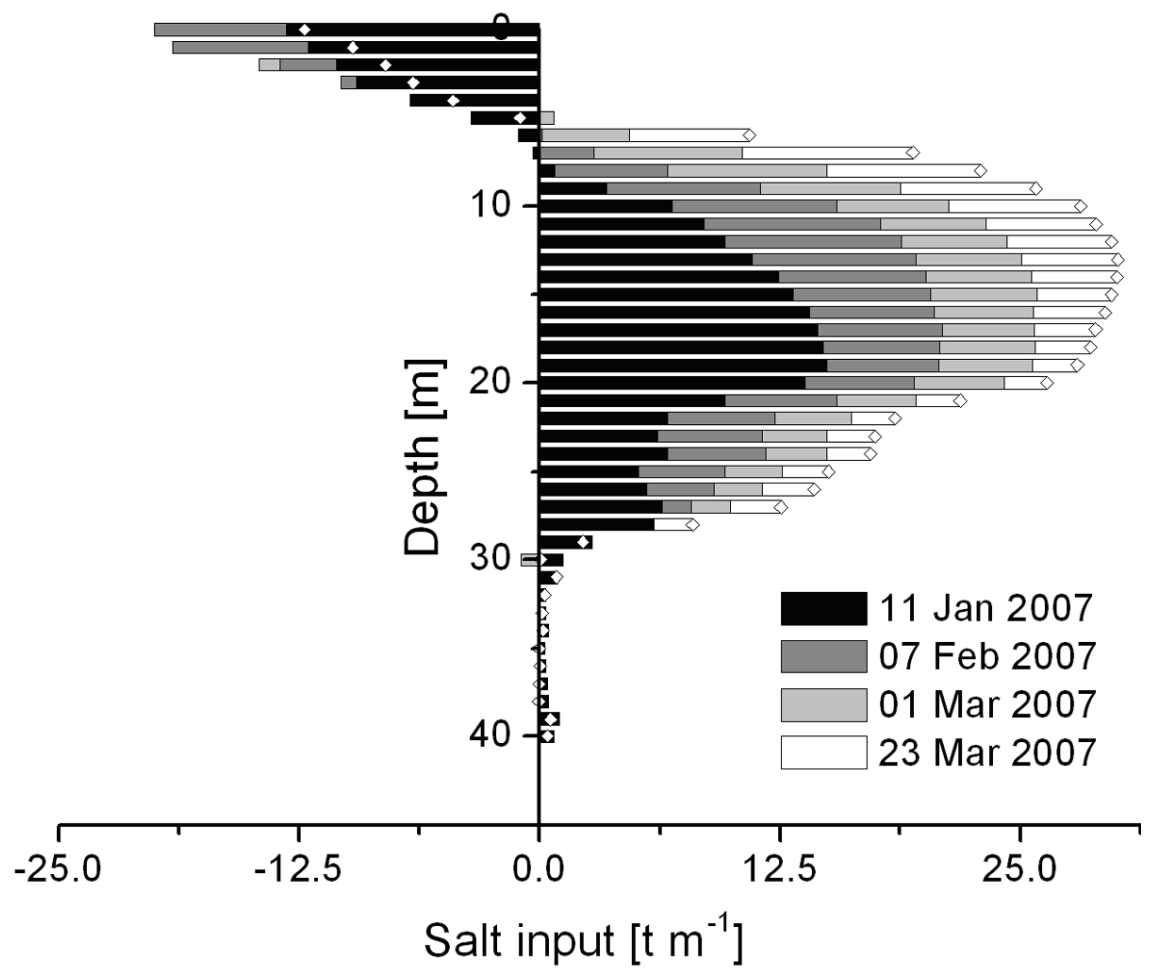

Fig. 7. Net salt input to Lej da San Murezzan between 17 December 2006 and the date given in the legend. The values from 23 March 2007 are additionally marked with open white diamonds to indicate the values that are lower than those from earlier dates. Since the salt input was mainly due to calcium sulfate, the true input could have been up to $25 \%$ lower than the values shown here (see text).

Tab. 1: Concentrations of major ions in the water samples from Lej da San Murezzan and its tributaries Inn and Ovel dal Mulin. ${ }^{(a)}$ calculated from alkalinity, assuming alkalinity is only due to $\mathrm{HCO}_{3}^{-}{ }^{-}{ }^{\text {(b) }}$ the unusual composition of Ovel dal Mulin led to difficulties in the analysis. Water samples from 17 October 2006 and 11 January 2007 were therefore each measured 3 times with different dilutions, and for all ions the three to four results that were within reasonable range were averaged. ${ }^{(c)}$ average of samples from 17 October 2006 and 11 January 2007.

Location / Depth $\quad \mathrm{Cl}^{-} \quad \mathrm{SO}_{4}^{2-} \quad \mathrm{HCO}_{3}^{-(\text {a) }} \quad \mathrm{Na}^{+} \quad \mathrm{K}^{+} \quad \mathrm{Ca}^{2+} \quad \mathrm{Mg}^{2+} \quad$ Alkalinity

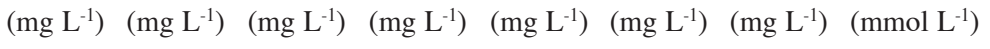

\begin{tabular}{|c|c|c|c|c|c|c|c|c|}
\hline \multicolumn{9}{|c|}{ Lej da San Murezzan, 26 October 2006} \\
\hline 0 & 1.5 & 29.7 & 59.4 & 2.2 & 0.9 & 23.2 & 3.7 & 0.97 \\
\hline 10 & 1.3 & 29.6 & 55.8 & 2.0 & 0.9 & 22.3 & 3.2 & 0.91 \\
\hline 20 & 1.3 & 31.6 & 56.1 & 2.1 & 0.9 & 22.2 & 3.7 & 0.92 \\
\hline 30 & 2.2 & 78.0 & 66.2 & 2.6 & 1.1 & 38.9 & 5.7 & 1.09 \\
\hline 38 & 2.7 & 81.6 & 69.5 & 2.8 & 1.1 & 41.8 & 5.9 & 1.14 \\
\hline \multicolumn{9}{|c|}{ Lej da San Murezzan, 11 January 2007} \\
\hline 2.5 & 2.1 & 47.8 & 34.5 & 2.1 & 0.6 & 22.3 & 3.9 & 0.57 \\
\hline 10 & 1.7 & 45.8 & 62.5 & 1.0 & 1.0 & 26.7 & 4.3 & 1.02 \\
\hline 20 & 1.7 & 51.2 & 62.0 & 1.1 & 0.6 & 32.2 & 4.7 & 1.02 \\
\hline 25 & 1.8 & 54.2 & 63.8 & 1.1 & 0.6 & 33.9 & 4.9 & 1.05 \\
\hline 30 & 2.1 & 67.4 & 67.6 & 1.3 & 1.5 & 39.4 & 5.7 & 1.11 \\
\hline 35 & 2.1 & 73.6 & 76.7 & 1.4 & 0.7 & 43.3 & 5.9 & 1.26 \\
\hline 40 & 2.2 & 71.7 & 80.0 & 1.3 & 1.0 & 42.0 & 6.0 & 1.31 \\
\hline Ovel dal Mulin (b) & 1.5 & 990.3 & 139.6 & 4.4 & 1.4 & 378.8 & 47.3 & 2.29 \\
\hline $\operatorname{Inn}(c)$ & 2.0 & 17.2 & 61.6 & 1.5 & 0.9 & 18.7 & 3.3 & 1.0 \\
\hline
\end{tabular}


river Ovel dal Mulin that enters the lake at its northern shore (Fig. 1). This river has a typical discharge of 50$60 \mathrm{~L} \mathrm{~s}^{-1}$ (the discharge measured with a Salinomadd flowmeter on 12 December 2006 was $54 \mathrm{~L} \mathrm{~s}^{-1}$ ), which is rather constant, as it is mainly fed by groundwater sources. The average contribution of Ovel dal Mulin to the water balance of the lake is less than $1 \%$, but can rise up to $5 \%$ in winter, when all other tributaries to the lake have minimum discharge. The conductivity at $25{ }^{\circ} \mathrm{C}, \kappa_{25}$, measured in Ovel dal Mulin was usually around $1800 \mu \mathrm{S} \mathrm{cm}^{-1}$. This corresponds to a salinity of $\sim 1.2 \mathrm{~g} \mathrm{~L}^{-1}$, for the composition of the river that mainly contains calcium sulfate. It should be noted, however, that the total measured ionic concentration in the water samples from the river was $30 \%$ higher $\left(1.57 \mathrm{~g} \mathrm{~L}^{-1}\right.$, Tab. 1$)$.

Based on these observations, a salt balance for the lake was established. The change in salt mass $M_{S}$ was estimated with a daily time step considering the inputs by Ovel dal Mulin (constant discharge $Q_{M u l}=54 \mathrm{~L} \mathrm{~s}^{-1}$ and salinity $S_{M u l}=1.2 \mathrm{~g} \mathrm{~L}^{-1}$ ) and by the River Inn (salinity $S_{I n n}$ as shown in figure $4 \mathrm{~d}$, daily discharge $Q_{I n n}$ according to FOEN [2007]), and the salt lost by the outflow (calculated from the average daily salinity in the top $5 \mathrm{~m}$ of the water column, $S_{\text {Surf }}$ linearly interpolated between the CTD profiles):

$$
\frac{d M_{S}}{d t}=Q_{M u l} \times S_{M u l}+Q_{I n n} \times S_{I n n}-\left(Q_{M u l}+Q_{I n n}\right) \times S_{\text {Surf }}
$$

The calculated and the observed salt contents differed by $<10 t$, except for 12 December 2007 when the difference was $44 \mathrm{t}$ (Fig. 8). This almost perfect agreement is certainly a coincidence given the uncertainty in the discharge and salinity of Ovel dal Mulin and the simplification of using a single ionic composition for calculating salinity from conductivity in the lake. Nevertheless, it clearly confirms that the observed salinity stratification can be explained by the effects of these two inflowing rivers.

\subsection{Consequences of the salinity stratification}

The salinity stratification caused by the small river Ovel dal Mulin has two important consequences for the lake, which need to be considered for its future management. The stable stratification increases the energy required for mixing the water column. Therefore, despite its lower depth, stronger winds are required to completely mix Lej da San Murezzan than it is the case for the two upstream lakes Lej da Silvaplauna and Lej da Segl. Complete mixing of the lake was not observed in spring 2006, autumn 2006, and spring 2007 (not all data shown). The oxygen profile measured on 17 July 2007 showed that the hypolimnion was completely anoxic, less than two months after the estimated date of convective mixing (Fig. 9). Based on these observations and the fact that earlier observations indicated that complete mixing occurs at least occasionally, the lake should be classified as intermittently meromictic or oligomictic.

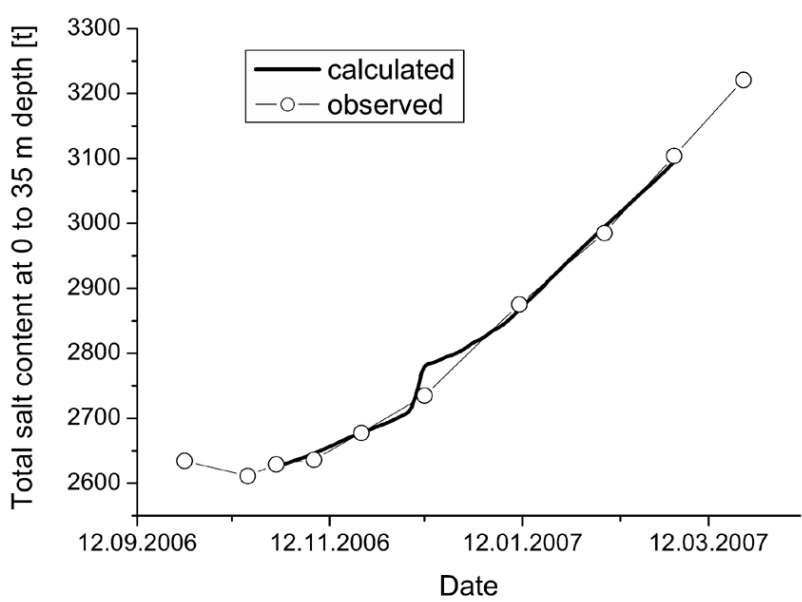

Fig. 8. Total salt content of Lej da San Murezzan between 0 and $35 \mathrm{~m}$ depth, calculated from the inflows of the Rivers Inn and Ovel dal Mulin, and the outflow, compared to the salt content calculated from the observed conductivity profiles.

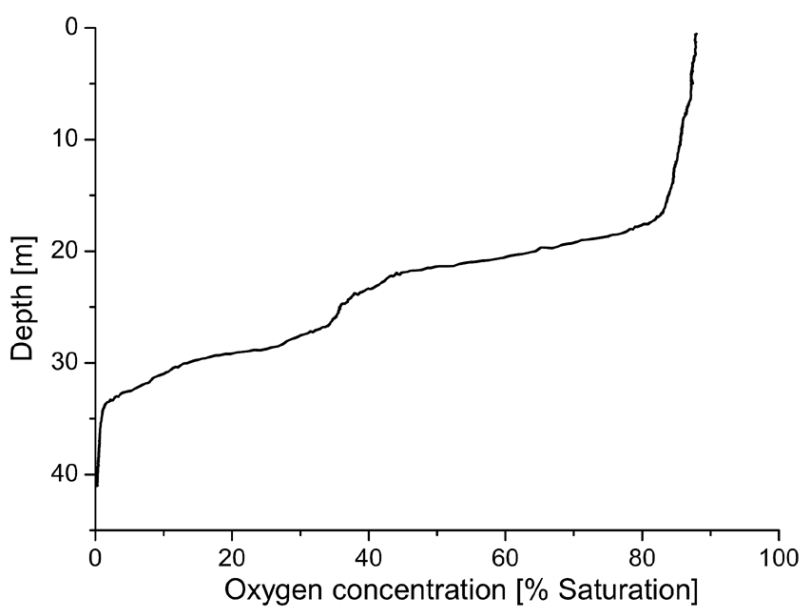

Fig. 9. Oxygen concentration (percentage saturation) observed in Lej da San Murezzan on 17 July 2007.

The relative depth in Lej da San Murezzan is 2.5\%, exactly the same as in Lej da Silvaplauna, and therefore certainly not the main cause for the meromixis. Meromixis is rather induced by the increased stability of the water column due to the inflow of the river Ovel dal Mulin. Oxygen depletion is further enhanced by the low ratio of hypolimnion to epilimnion volume, while the higher productivity of the lake is only of secondary importance. The low oxygen concentrations and the oligomictic state of Lej da San Murezzan must thus be considered to have mainly natural causes. However, observations in sediment cores indicate that oxygen availability must have been higher in the hypolimnion 
before 1910 (Züllig 1982). This indicates that without the anthropogenic nutrient inputs, the oxygen consumption was probably not sufficient to cause permanent anoxic conditions in the hypolimnion even if the lake may have mixed completely only occasionally.

Another important consequence of the stratification, as already mentioned in the literature review, is that it allows restratifying the reinjected water from the heat pump in the hypolimnion without any risk of disturbing the ice formation at the lake surface. The discharge of Ovel dal Mulin is similar to that of the heat pump, but its effect on the density of the hypolimnetic water is at least an order of magnitude larger. The density of Ovel dal Mulin water is $\sim 1 \mathrm{~g} \mathrm{~L}^{-1}$ higher than that of the hypolimnetic water. In comparison, a cooling by the heat pump from $4{ }^{\circ} \mathrm{C}$ to $1{ }^{\circ} \mathrm{C}$ leads only to a density change of $0.07 \mathrm{~g} \mathrm{~L}^{-1}$. Furthermore, due to the nonlinear temperature dependence of density, mixing of the reinjected water with ambient water will reduce the density effect, which is not the case for the almost linear salinity dependence of density. It is therefore safe to assume that the discharge of the heat pump will not prevent the build-up of the salinity stratification.

These findings need to be considered in the future management of the lake and especially of the river Ovel dal Mulin. A small part of the discharge of this river is already fed into the water supply system of St. Moritz during winter, and it has previously been suggested to bottle mineral water from the groundwater sources that feed this river. Based on our results, such changes in the discharge of the river Ovel dal Mulin could have important consequences. If this input were completely diverted from the lake, Lej da San Murezzan would most probably become dimictic like its neighbouring lakes. The effect would be similar to that observed in Hallstättersee, which changed from meromictic to holomictic after the elimination of chloride containing effluent inputs from salt mining to a small tributary (Jagsch et al. 2002). The hypolimnion of Lej da San Murezzan would be well supplied with oxygen at least for most of the year, and the risk of disturbing the ice formation with the heat pump discharge would have to be reconsidered.

\section{ACKNOWLEDGMENTS}

The authors would like to thank M. Schurter, S. Schubert, F. Muvundja, N. Pasche and the municipality of St. Moritz for their support during the field work,"R Stierli for chemical analysis", ewz (Elektrizitätswerk der Stadt Zürich) for inspiring us to investigate the stratification in this lake in more detail, and A. Wüest for helpful scientific discussions and a critical review of the manuscript.

\section{REFERENCES}

Bosli-Pavoni, M. 1971. Ergebnisse der limnologischen Untersuchungen der Oberengadiner Seen. Schweiz. Z. Hydrol., 33: 386-409.

FOEN. 2007. Hydrological yearbook of Switzerland. Federal Office for the Environment (FOEN), Bern.

Jagsch, A., H. Gassner \& M. Dokulil. 2002. Long-term changes in environmental variables of Traunsee, an oligotrophic Austrian lake impacted by the salt industry, and two reference sites, Hallstättersee and Attersee. Water Air Soil Poll. Focus, 2:9-20.

Hakala, A. 2003. Meromixis as a part of lake evolution Observations and a revised classification of true meromictic lakes in Finland. Boreal Environ. Res., 9: 37-53.

Hutchinson, G.E. 1957. A treatise on Limnology. 1. Geography, physics, and chemistry. John Wiley \& Sons, New York: 1015 pp.

Kjensmo, J. 1997. The influence of road salts on the salinity and the meromictic stability of Lake Svinsjøen, southeastern Norway. Hydrobiologia, 347: 151-158.

Lewis Jr., W.M. 1983. A revised classification of lakes based on mixing. Can. J. Fish. Aquat. Sci., 40: 1779-1787.

Limnex, 1994. Gewässerzustand und Gewässerschutzmassnahmen im Oberengadin. Zürich: 75 pp.

Schmassmann, W. \& H. Schmassmann. 1948. Chemische Untersuchungen im St. Moritzersee. Schweiz. Z. Hydrol., 10: 23-35.

Walker, K.F. \& G.E. Likens. 1975. Meromixis and a reconsidered typology of lake circulation patterns. Verh. Int. Ver. Limnol., 19: 442-458.

Wehrli, B., A. Lotter, T. Schaller \& M. Sturm. 1997. High-resolution varve studies in Baldeggersee (Switzerland): Project overview and limnological background data. Aquat. Sci., 59: 285-294.

Wüest, A. et al. 1996. Combined effects of dissolved solids and temperature on the density stratification of Lake Malawi. In: T.C. Johnson \& E.O. Odada (Eds), The limnology, climatology and paleoclimatology of the East African Lakes. Gordon and Breach, Toronto: 183-202.

Züllig, H. 1982. Untersuchungen über die Stratigraphie von Carotinoiden im geschichteten Sediment von 10 Schweizer Seen zur Erkundung früherer Phytoplankton-Entfaltungen. Schweiz. Z. Hydrol., 44: 1-98.

Received: November 2007

Accepted: March 2008 